\title{
Credit scoring for Vietnam's retail banking market : implementation and implications for transactional versus relationship lending
}

\author{
Citation for published version (APA):
}

Dinh, K., \& Kleimeier, S. (2006). Credit scoring for Vietnam's retail banking market : implementation and implications for transactional versus relationship lending. METEOR, Maastricht University School of Business and Economics. METEOR Research Memorandum No. 012 https://doi.org/10.26481/umamet.2006012

Document status and date:

Published: 01/01/2006

DOI:

10.26481/umamet.2006012

Document Version:

Publisher's PDF, also known as Version of record

Please check the document version of this publication:

- A submitted manuscript is the version of the article upon submission and before peer-review. There can be important differences between the submitted version and the official published version of record.

People interested in the research are advised to contact the author for the final version of the publication, or visit the DOI to the publisher's website.

- The final author version and the galley proof are versions of the publication after peer review.

- The final published version features the final layout of the paper including the volume, issue and page numbers.

Link to publication

\footnotetext{
General rights rights.

- You may freely distribute the URL identifying the publication in the public portal. please follow below link for the End User Agreement:

www.umlib.nl/taverne-license

Take down policy

If you believe that this document breaches copyright please contact us at:

repository@maastrichtuniversity.nl

providing details and we will investigate your claim.
}

Copyright and moral rights for the publications made accessible in the public portal are retained by the authors and/or other copyright owners and it is a condition of accessing publications that users recognise and abide by the legal requirements associated with these

- Users may download and print one copy of any publication from the public portal for the purpose of private study or research.

- You may not further distribute the material or use it for any profit-making activity or commercial gain

If the publication is distributed under the terms of Article $25 \mathrm{fa}$ of the Dutch Copyright Act, indicated by the "Taverne" license above, 


\title{
Credit Scoring for Vietnam's Retail Banking Market: Implementation and Implications for Transactional versus Relationship Lending
}

\author{
by
}

Dinh Thi Huyen Thanh \& Stefanie Kleimeier*

Limburg Institute of Financial Economics (LIFE)

Faculty of Economics and Business Administration (FdEWB)

Maastricht University

P.O. Box 616

6200 MD Maastricht

The Netherlands

\begin{abstract}
As banking markets in developing countries are maturing, banks face competition not only from other domestic banks but also from sophisticated foreign banks. Combined with a dramatic growth of consumer credit and increased regulatory attention to risk management, the development of a well-functioning credit assessment framework is essential. As part of such a framework, we propose a credit scoring model for Vietnamese retail loans. First, we show how to identify those borrower characteristics that should be part of a credit scoring model. Second, we illustrate how such a model can be calibrated to achieve the strategic objectives of the bank. Finally, we assess the use of credit scoring models in the context of transactional versus relationship lending.
\end{abstract}

JEL Classifications: G21; G28; O16.

Keywords: $\quad$ retail banking; emerging markets; credit scoring; default risk; transactional lending; relationship lending.

* Corresponding author. Tel.: +31-43-3883733; fax: +31-43-3884875; email:

s.kleimeier@finance.unimaas.nl 


\section{Introduction}

Are retail loans simply small versions of syndicated loans with single-lender syndicates? Advocates of relationship lending tend to answer this question with 'no'. Since retail borrowers are typically unrated small and medium size enterprises (SMEs) or individuals, information about them is not readily available but needs to be obtained through close contact over the life of a bank-client relationship. Relationship lending is thus based on soft, proprietary information. Loan approval or pricing decisions are not only determined by exact characteristics such as the borrower's income or collateral but to a large extent also by qualitative information such as the borrower's character, reputation, or standing in the community. However, banks have realized that relationships are expensive to maintain and that loan decisions based on relationship criteria might not always be profit maximizing. Despite these disadvantages, large banks in industrialized countries have increasingly become interested in retail lending mainly driven by the higher return on assets in this market segment. With them, they are bringing their skills in transactional lending where lending decisions are based on exact, quantifiable borrower characteristics supported by a quantitative model, such as a credit scoring model (CSM). In the US, the most widely used models in retail banking are those of Fair Isaac and Co. Inc. who developed models for small business trade credit in 1998, small business credit in 1999, and finally personal credit in 2001.

The US is undoubtedly a country with a high availability of retail credit information where banks can easily implement CSMs and reap the benefits in terms of reduced loan losses, lower administrative cost, larger geographical reach, or increase in loan volume. ${ }^{1}$ More recently, these models have been applied in other developed countries such as Canada or Japan. In the retail banking markets of developing countries where relationship lending characterized by severe credit rationing is the norm, there are substantial implication hurdles. Many banking markets are characterized by poor lending practices including insider lending or fraud. Additionally, banks, i.e. small banks or micro-financiers lack the necessary data on borrower characteristics and their credit histories to design reliable CSMs. It is therefore not surprising that only a few of the largest banks in developing countries have developed such models. Given this lack of data for most financial intermediaries, data pooled from various banks - as used in the US by Fair Isaac - would be a solution. However, up to now the dominant banks in developing markets seem intent on protecting their market shares in the profitable retail segment and are thus reluctant to share information. The World Bank together

\footnotetext{
${ }^{1}$ See Allen et al. (2004) for details.
} 
with Fair Isaac is currently investigating the feasibility of collecting pooled data for Brazil, Colombia and Mexico. ${ }^{2}$

This paper addresses the lack of information on retail credit scoring from a different angle. Based on detailed data of one of Vietnam's commercial banks, we develop a CSM for retail loans. In the process, we identify which borrower characteristics a bank needs to collect and how these can be combined into a scoring model. Furthermore, we develop a flexible approach which is build on the principles of transactional lending but leaves room for relationship lending. The remaining of the paper is structured as follows: Section 2 presents a general CSM as currently applied for consumer credit and illustrates the modeling steps and decisions that have to be taken. In section 3 a model is implemented using the retail loan population of a Vietnamese commercial bank. Specific features of the model are explored in section 4 with specific focus on profit implications and relationship lending. Section 5 concludes.

\section{A credit scoring methodology for retail loans}

CSMs are commonly structured along the lines of Altman's (1968) Z-score model. In a first step, a CSM uses historical data combined with a statistical technique - a linear probability model, a logit or probit regression model, or multiple discriminant analysis - in order to identify which borrower characteristics are best able to distinguish between defaulted and nondefaulted loans. In a second step, the model is used to calculate a score for each new loan applicant. In principle a higher score indicates better expected performance of the borrower and thus a lower probability of default (PD). This score needs to be compared to a cut-off rate to determine whether the application is accepted, rejected or requires further assessment. Thus, a calibration of the model is necessary such that an optimal cut-off rate is determined.

Regarding the first step, we opt in this study for the implementation of a logistic regression model. Based on a sample of existing loans, both borrower characteristics and default status are observed. We are in fact dealing with a problem of unobservable variables as we can only observe ex post whether or not a borrower defaulted but cannot directly measure a borrower's ex ante PD. The logistic regression technique overcomes this problem by directly estimating this probability and has therefore been the methodology of choice for retail credits (see Schreiner, 1999). ${ }^{3}$ This technique assumes the existence of a continuous variable $Z_{j}$ which

\footnotetext{
${ }^{2}$ See Miller and Rojas (2004) for details.

${ }^{3}$ There is an extensive literature on classification accuracy of different methodologies including next to logistic regressions also linear discriminant analyses, classification trees, and neural networks. Based on findings by
} 
is defined as the probability that applicant $j$ defaults and can be modeled as a linear function of a set of variables $\mathrm{x}$ :

$\mathrm{Z}_{\mathrm{j}}=\mathrm{W}^{\prime} \mathrm{x}=\mathrm{w}_{1} \mathrm{x}_{\mathrm{j} 1}+\mathrm{w}_{2} \mathrm{x}_{\mathrm{j} 2}+\ldots+\mathrm{w}_{\mathrm{k}} \mathrm{x}_{\mathrm{jk}}$

where $w_{k}$ is the coefficient of the $k^{\text {th }}$ variable and $x_{j k}$ is the value of variable $k$ for applicant $j . Z_{j}$ is known as Z-Score of the $\mathrm{j}^{\text {th }}$ applicant. If $\mathrm{Z}$ were observable, an OLS regression could simply be fitted to estimate equation (1). However, since $\mathrm{Z}$ is unobservable, default can only be defined ex post as a 0-1 dummy. Equation (2) then derives the default probability $\pi$ using an iterative maximum likelihood estimation method. Here, larger values of $\pi$ reflect a higher PD.

$\pi_{\mathrm{j}}=\frac{1}{1+\mathrm{e}^{-\left(\mathrm{W}^{\prime} \mathrm{x}\right)}}$

After deciding on the methodology, a choice has to be made among the variables $\mathrm{x}$ that should initially be considered for equation (1). There is no overall consensus. Some credit scoring models start out with as many as 50 variables including for example First Data Resources' model for credit cards lenders (Mester, 1997) or Caisse Nationale de Crédit Agricole du Burkina Faso for rural microfinance (Viganó, 1993). Efficiency and applicability however stipulate that these numbers are reduced to as few as 10 to 15 . The different procedures that can facilitate this reduction are explained in more detail below. Table 1 presents a list of the more commonly used variables for retail CSMs. Viganó's (1993) and Schreiner's (1999) CSMs are the only ones developed explicitly for developing countries. Whereas in CSMs for business loans, the variables are relatively similar across countries and limited to financial statement data (Allen et al., 2004), the variables relevant in retail credit scoring models are clearly different. Similar to the financial statement data for firms, direct measures of the financial strength of the borrower such as income or value of the home are included. Given the limited available of such proxies for individuals, proxies that measure the financial strength of a borrower indirectly (education, household size, years at employer, or postal code) need to be included.

[Insert Table 1 about here]

Boyle et al. (1992), Desai et al. (1996, 1997), Henley (1995), Srinivasan and Kim (1987), and Yobas et al. (1997) as reported by Thomas (2000), we opt for the logistic regression method. 
Next to the choice of independent variables, two further issues need to be considered: The coding of the variables and the procedure used to identify the relevant variables. Regarding the first issue, note that coding is necessary for qualitative as well as quantitative variables. The coding of quantitative variables is required when the relationship between the variable and default is not linear. Consider for example the relationship between loan duration and default for Vietnamese retail loans as presented in Panel A of Figure 1. As Thomas (2000) argues, instead of trying to map such a curve as a straight line, one could either model it as a more complex curve or one could decided to group consumers into a number of categories and think of duration as a categorical variable. The later approach is more commonly used in credit scoring mainly because this procedure can also applied to qualitative variables. Based on the distribution shown in Panel A, categories of $<13$, 13-24, 25-36, 37-48, $>48$ months are chosen. Panel B illustrates how the categories reflect the default-duration relationship.

\section{[Insert Figure 1 about here]}

To complete the coding of the variables, a value has to be attached to each category. According to Boyle et al. (1992) there are three possibilities at this stage. First, binary variables can be defined for each possible category of each variable. For duration shown in Figure 1 there are five categories. Thus, four dummy variables must be defined which are coded 1 if the loan duration falls into a given category and zero otherwise. When the number of categories is high, this can however substantially increase the number of independent variables $\mathrm{x}$ in the model. A second method is a location model that constructs a different linear discriminant function over the continuous variables for each possible combination of the values of the discrete variables. Third, the variables can be coded based on distribution of defaulted and non-defaulted loans in the sample. If a variable has $\mathrm{m}$ categories, let $\mathrm{g}_{\mathrm{i}}$ be the number of good (non-defaulted) loans who belong to the $i^{\text {th }}$ category and $b_{i}$ the number of bad (defaulted) loans who belong to the $i^{\text {th }}$ category. $\mathrm{G}$ and $\mathrm{B}$ are the total number of good and bad loans in the whole sample, respectively, such that

$$
\mathrm{G}=\sum_{\mathrm{i}=1}^{\mathrm{m}} \mathrm{g}_{\mathrm{i}} \quad \text { and } \quad \mathrm{B}=\sum_{\mathrm{i}=1}^{\mathrm{m}} \mathrm{b}_{\mathrm{i}}
$$


Instead of using a simple coding rule ${ }^{4}$, a value based on $g_{i}, b_{i}, B$, and $G$ is assigned to the $i^{\text {th }}$ category. Boyle et al. (1992) describe several possible combinations which are related to estimates of probability odds or log probability odds of the good and bad loans in the $i^{\text {th }}$ category:

$\mathrm{g}_{\mathrm{i}} / \mathrm{b}_{\mathrm{i}}$

$g_{i} /\left(g_{i}+b_{i}\right)$

$b_{i} /\left(g_{i}+b_{i}\right)$

$\log \left(g_{i} /\left(g_{i}+b_{i}\right)\right)$

$\ln \left(g_{\mathrm{i}} / \mathrm{b}_{\mathrm{i}}\right)+\ln (\mathrm{B} / \mathrm{G})$

Crook et al. (1992) recommend the last of these estimates because of its sophistication. We follow this recommendation when coding our variables. For our exemplary, quantitative variable loan duration, the result is shown in Panel C of Figure 1. A special problem arises for qualitative variables. When the number of possible categories is very large, for example for variables such as postcode or occupation, coding all categories becomes infeasible. For such cases, Thomas (2000) and Boyle et al. (1992) recommend aggregating values of similar default probability measured as $b_{i} /\left(g_{i}+b_{i}\right)$.

Once the variables have been coded, equation (1) can be estimated. As is evident from the development of retail CSMs in developed countries, the model can initially contain a large number of variables. Whereas this might be statistically feasible for large samples, there are practical considerations. Too many questions in an application form deter loan applicants, who will not answer all questions or apply for a loan elsewhere. It is thus critical to determine how many and which variables incorporated in the model. Henley and Hand (1997) discuss three approaches to select variables. First, expert knowledge and a feeling for the data and characteristics can help in the selection. The latter will help in excluding non-predictive variables and the former will help in justifying the chosen variables. Second, a stepwise statistical procedure can be used. For example, forward stepwise methods sequentially add variables to maximize the model's predictive accuracy. Third, individual variables are selected based on the difference between the distribution of defaulted versus non-defaulted loans for that variable. One common used measure is the information value, defined as:

\footnotetext{
${ }^{4}$ A simple rule would assign the value of 1 to category with lowest PD, 2 to category with second highest PD, etc.
} 
$\sum_{j}\left(p_{i j}-q_{i j}\right) w_{i j}$

where $\mathrm{p}_{\mathrm{ij}}$ is the number of non-defaulted loans in category $i$ that have a value of $j$ divided by the total of non-defaulted loans in category i. Correspondingly, $\mathrm{q}_{\mathrm{ij}}$ is calculated for defaulted loans. Typically, any characteristic $j$ with an information value larger than 0.1 will be included in the model. In this study, we apply the first and second approach. The first approach will be used to identify an initial set of 22 variables. The second approach will then be applied to select the most relevant variables from this initial set.

When the final version of the CSM has been determined and the coefficients $w_{j}$ have been estimated, the CSM should be tested for its predictive accuracy. This is best done out-ofsample as the model predicts over-accurately in-sample. In other words, a different sample of defaulted and non-defaulted loans should be used to for step 1, the development of the model, and step 2, the calibration of the model. Thus, the PD for each loan in the calibration-sample is estimated. This PD is then compared to a cut-off value to predict whether the loan applicant will be a good (non-defaulting) or bad (defaulting) borrower. Initially, a cut-off value of $50 \%$ can be chosen. In this case, an applicant who's estimated PD is greater than $50 \%$ will be classified as a bad (defaulting) loan and an applicant who's estimated PD is less than $50 \%$ will be classified as a good (non-defaulting) loan. This classification is then compared to the observed event of default to establish the accuracy of the model. A classification table as shown in Table 2 is commonly employed at this stage. $\mathrm{G}_{\mathrm{g}}$ represents the number of correctly classified good loans whereas $G_{b}$ represents the number of good loans that are incorrectly classified as bad loans. Similarly, $B_{b}$ represents the number of correctly classified bad loans whereas $\mathrm{B}_{\mathrm{g}}$ represents the number of bad loans that are incorrectly classified as good loans. The percentage of correctly classified (PCC) loans is an accuracy measure that is easily obtained from this table. As an overall measure, the percentage of correctly classified total loans is defined as the number of correctly classified loans relative to the total number of loans:

$\mathrm{PCC}_{\text {total }}=\left(\mathrm{G}_{\mathrm{g}}+\mathrm{B}_{\mathrm{b}}\right) /\left(\mathrm{G}_{\mathrm{g}}+\mathrm{G}_{\mathrm{b}}+\mathrm{B}_{\mathrm{b}}+\mathrm{B}_{\mathrm{g}}\right)$

Furthermore, the percentage of correctly classified bad loans is defined as proportion of correctly classified bad loans to the total number of observed bad loans:

$\mathrm{PCC}_{\mathrm{bad}}=\mathrm{B}_{\mathrm{b}} /\left(\mathrm{B}_{\mathrm{b}}+\mathrm{B}_{\mathrm{g}}\right)$ 
Finally, the percentage of correctly classified good loans is defined as proportion of correctly classified good loans to the total number of observed good loans:

$\mathrm{PCC}_{\text {good }}=\mathrm{G}_{\mathrm{g}} /\left(\mathrm{G}_{\mathrm{g}}+\mathrm{G}_{\mathrm{b}}\right)$

Though simple to use, PCC may not always be an appropriate accuracy measure. It implicitly assumes that the costs of misclassification of bad and good loans are equal. For banks, one classification error may, however, be much more expensive than another. Another, often violated assumption of PCC is that the class distribution is constant over time and relatively balanced (Provost et al., 1998). Baesens et al. (2003) use two additional accuracy measures called sensitivity (SENS) and specificity (SPEC). In contrast to $\mathrm{PCC}_{\mathrm{bad}}$ which relates the predicted bad loans to the total number of observed bad loans, SPEC is defined as proportion of correctly classified bad loans to the total number of predicted bad loans:

$\mathrm{SPEC}=\mathrm{B}_{\mathrm{b}} /\left(\mathrm{B}_{\mathrm{b}}+\mathrm{G}_{\mathrm{b}}\right)$

Here the denominator corresponds to the total number of rejected loans. SENS is defined as number classified good loans relative to the total number of predicted good loans:

$\mathrm{SENS}=\mathrm{G}_{\mathrm{g}} /\left(\mathrm{G}_{\mathrm{g}}+\mathrm{B}_{\mathrm{g}}\right)$

It is easy to understand that banks want to minimize both $B_{g}$ and $G_{b}$ at the same time. However, reducing $B_{g}$ comes at the expense of increasing $G_{b}$, and vice versa. Thus banks should take into account its differences in cost arising from misclassified good versus bad loans. For most banks the cost of $B_{g}$ will be higher than the cost $G_{b}$ and the CSM can be calibrated based on SENS. In section 4.1. we introduce a more advanced method that takes these two costs explicitly into account.

[Insert Table 2 about here]

\section{An application to the Vietnamese retail lending market}

In 1987, Vietnam started its transformation to a market economy. Part of this process is the replacement of the monopoly of state-owned banks by a two-level banking system consisting of a national central bank on one level and state-owned as well as commercial banks 
on the other level. ${ }^{5}$ Projects to modernize the inter-bank market, to create an international accounting system, and to allow outside audits of major Vietnamese banks are ongoing. However, the banking system continues to suffer from lack of capital, inadequate provisions for possible loan losses, low profitability, inexperience in capital markets, and the slow pace of institutional reform. With respect to risk assessment and management there are numerous difficulties including a lack of transparency in non-performing loan disclosure. There is for example no uniform definition of a non-performing loan. It is thus not surprising that nonperforming loan rates range from $3 \%$ based on banks' official financial reports to $35-70 \%$ based on figures by the World Bank or IMF. ${ }^{6}$ In order to improve risk management, The Vietnam's central bank is currently reviewing its risk management regulations in light of Basel II. As part of a broader strategy, which also addresses the banks' business strategy, assets and liability management, and internal audit, all state-owned commercial banks and joint-stock commercial banks have been asked to develop a comprehensive credit manual which takes international practices in risk management into account. The development of a proper CSM is an important building block within this credit manual.

To illustrate the current state of credit assessment in Vietnam, Table 3 summarizes the most advanced credit scoring system as it is currently used by one of Vietnam's commercial banks. This bank scores applicants based on 14 variables in a two step procedure. In a first assessment round, a loan applicant is evaluated based on the nine criteria listed in Panel A. If her score is higher than a certain threshold, she will be evaluated again based on the criteria listed in Panel B. Otherwise, she is rejected directly without any further consideration. Based on the total score from both rounds, the loan applicant will be rated as shown in Panel C. From the 14 variables used to score applicants, only four variables are included in Crook et al.'s (1992) list of the 24 most typical variables as given in Table 1. These are time with present employer, residential status, number of dependants, and income. The incorporation of these factors into the credit assessment system of a commercial bank in Vietnam might indicate that despite the difference in economic development between Vietnam and industrialized countries, some of the same factors are relevant for the credit decision making. Though considered as a good starting point, the credit assessment system presented in Table 3 is a qualitative method where scores and weights of each variable are not the result of a statistical approach but based on experience and judgment of the credit officer. More importantly, with this system, the bank

\footnotetext{
${ }^{5}$ Currently this second level of the Vietnamese banking system contains 5 state-owned commercial banks, 1 social policy bank, 31 foreign bank branches, 40 foreign credit institution representative offices, 5 joint-venture commercial banks, 36 domestic joint-stock commercial banks, 7 finance companies, and the Central People's Credit Fund System with 23 branches and 888 local credit funds.
} 
cannot estimate PD and therefore can not exploit this estimate in improving its risk management. Given the high levels of non-performing loans, the development of a more sophisticated CSM seems indeed necessary. In the remainder of this section, we develop such a model based on the retail loan portfolio of another of Vietnam's commercial banks.

[Insert Table 3 about here]

\section{$\underline{\text { 3.1 Sample selection }}$}

To develop a CSM, all retail loans that were outstanding on a given day in 2005 were extracted from the database of one of Vietnam's commercial banks. This loan population contains mortgages, consumer loans, credit card loans or business loans to borrowers from all over Vietnam. The bank classifies loans with more than 90 days of payment delay or at least three consecutive payment delays as defaulted. Defaulted loans account for $4.9 \%$ in the total population. Currently, the bank uses more than 30 characteristics in its loan decision. There are, however, many missing values. ${ }^{7}$ Overall, less than $10 \%$ of the applicants have full information for all characteristics. In order to obtain a sufficiently large sample of loans with complete information, 22 variables with relatively few missing values are identified. This leads to a sample of 56,037 loans. This sample contains 3.3\% defaulted loans which is only slightly lower than $4.9 \%$ in the total loan population. ${ }^{8}$ This could imply that a customer who sufficiently fills in the application form has a lower PD than someone who does not properly complete the application form. This is consistent with one of strategies used in practice for coping with missing component as stated by Henley (1995): "a refusal to answer a particular question may be indicative of greater risk". Our sample of 56,037 loans is thus based on the 22 variables where the criteria for selecting these variables are based on the expert knowledge approach discussed above. These can overrule the requirement of no missing values and our sample thus contains the category 'other' which covers missing values.

The characteristics of our sample will become more evident section 3.1. when we discuss the 22 different variables included in our CSM. Therefore, only a quick overview of

\footnotetext{
${ }_{7}^{6}$ See Loi (2004).

7 Such values may be structurally missing (e.g. question which are asked conditionally on the responses to previous questions). Alternatively, missing values might be due to a deficient information system in some branches or due to customers who themselves were not willing to completely fill in the application forms.

${ }^{8}$ The population PD of $4.90 \%$ is in line with the PD reported in general on banks' financial statements but rather far below the alternative figures of $35 \%$ to $70 \%$ reported by the World Bank. For the purpose of this study we assume that the data provided to us by the bank accurately records all defaults. As long as any potential misreporting is not structurally related to borrower characteristics (i.e. the variables included in our credit scoring model), this assumption is acceptable as it does not affect the estimation of the model but would only lead to an over-statement of the predictive accuracy of the model.
} 
the sample will be given at this point. The bank distinguishes five borrower groups based on their loans' purpose: Customers borrowing money to finance their business (business); customers borrowing money for purchase or maintenance of their house (house); customers borrowing money to finance mobile assets such as the purchase of a car or motorbike where the asset serves as collateral (collateralized); customers borrowing money for living expenses or consumption without collateral (general credit); and customers borrowing money via the bank's credit card to finance their special expenses such as studying abroad (credit card). As this list shows, our sample includes consumer as well as commercial loans. In Vietnam as general and in our bank as particular, these business loans are used to finance relatively small and private businesses. Due to the lack of reliable up-to date financial data on those small commercial borrowers and due to the fact that the boundary between the private and business property of the entrepreneur is often vague, these loans can only be assessed based on the personal information of the entrepreneur. In terms of loan numbers, business loans and general credits are the most frequently occurring loan types and account for $36 \%$ and $39 \%$ of all loans. The other three loan types account for $5 \%$ to $10 \%$ of all loans, each. In terms of value, however, housing loans have a higher weight (36\%) due to their larger average size of 244 million Vietnamese Dong (VND) compared to business loans (VND 127 million, 39\%) or general credits (VND 37 million, 17\%).

Finally, note that because sample contains only information of applicants who were accepted, it is not representative of the population who might be the future customers. We also cannot perceive how those applicants who were rejected would have performed if they had been accepted. A solution is the out-of-sample calibration of the model described in the previous section. We therefore divide the 56,037 loans into two sub-samples. The initial sample contains 30,994 loans of which 1026 (3.3\%) are in default and the hold-out sample contains 25,043 applicants of which 798 (3.2\%) are in default.

\subsection{Variable selection and coding}

As mentioned above, 22 variables are initially selected for inclusion in the CSM. These variables are listed in Table 4 and include nine quantitative and 13 qualitative variables. In comparison to the currently existing credit scoring models, our selection overlaps widely with Crook's (1992) as well as Viganó's (1993) list of commonly used variables. ${ }^{9}$ Variables that

\footnotetext{
${ }^{9}$ Viganó (1993) develops her CSM for small business loans to individuals and therefore focuses less on personal characteristics and more on entrepreneurial characteristics. Among her 53 variables, she includes the applicant's gender, age and martial status but not number of dependents or residential status.
} 
seem to be unique to developing countries are gender, loan duration, marital status, and education. As already illustrated in section 2 for loan duration, each variable is first split into categories and then coded. The categories as well as the associated PD can also be found in Table 4. When coding all variables based on equation (4e), two issues arise. First, in our sample $\ln (\mathrm{B} / \mathrm{G})$ is constant. In practice, however, when banks are updating their $\mathrm{CSM}$ at regular intervals, this value will change with every update. Second, some qualitative variables like occupation or region have a large number of different values and thus possible categories. For example, 20 different occupations appear in the loan applications. As outlined in the previous section, we pool these 20 occupations according to their similarity of probability of default. Any occupations for which there were no defaulted loans were included in the category with lowest probability of default. This procedure is applied to all qualitative variables with a high number of different initial values.

[Insert Table 4 about here]

The 22 variables included in the model are discussed in detail below starting with the borrower's personal characteristics and followed by variables describing the borrower's banking relationship.

Income presents the borrower's monthly income in millions of VND. This is a commonly used proxy of the borrower's financial wealthy and his ability to repay. Note that in our sample, the average (median) monthly income is 8.36 (4.0) million VND for non-defaulted and 1.85 (1.2) million VND for defaulted borrowers. In contrast, the average monthly income in Vietnam is only about 1.1 and 0.4 million VND for employees in the state and private sector, respectively (Nguyen, 2004). Thus, the bank's borrowers - including the defaulted ones - have an income that lies clearly above the national average. Interestingly and expectedly, the applicants who do not reveal their income have higher than average default rate of $4.07 \%$ versus $3.3 \%$.

Regarding education we expect that better educated people have more stable, higherincome employment and thus a lower PD. We therefore distinguish borrowers by the educational degree they hold.

Occupation is one of commonly incorporated variables since it is highly correlated with income. Based on the 20 different occupations found in the sample, five categories are formed that pool occupations with similar default rates. As shown in Table 4, these categories range 
from the highest default-rate category of military, police and journalists to the lowest defaultrate category of entrepreneurs and farmers.

Employer type documents the type of company for which a borrower works such as state-owned, foreign, joint-stock company, etc. It does not reflect industries or sectors which is coded via occupation. In Vietnam, the type of company can be a good proxy for income level and stability. For example, employees of foreign companies, which are known to pay rather high salaries, have the lowest probability of default. For this variable, missing values are also very informative as borrowers who do not answer this question show the highest default rates.

Time with employer measures the number of years that a borrower has been working for his current employer. The variable matters because it might reflect the satisfaction of the borrower with his current job. The higher the borrower's job satisfaction, the more stable their employment will be and the higher their ability to repay their loans (Crook et al., 1992). In our sample, however, defaulted borrowers have a slightly longer time with their employer but given the large standard deviation this might not be statistically significant. For Vietnam, time with employer might just proxy the same underlying relationship as age as younger people are switching jobs more often than older people while at the same time having lower default rates.

Age measures the borrower's age in years. It is often assumed that older borrowers are more risk adverse and will therefore be less likely to default. Thomas (2000) and Boyle et al. (1992) can also confirm this empirically. For our sample, however, the opposite seems to hold. The age variable is categorized into 5 groups: $18-24,25-35,36-45,46-64$, and older than 65 . With the exception of the 46-64 age group, the default rate increases steadily from about $1.98 \%$ to $4.66 \%$. This could either be due to the fact that banks are more hesitant to lend to younger borrowers are that older people are indeed less rather than more risk averse.

Gender can no longer be included in credit scoring models for many industrialized countries as it is deemed discriminatory. When developing a credit scoring framework, Schreiner (2003) argues that fair discrimination - for example based on the statistical default rates of men versus women - is acceptable as it is based on quantifiable data. The alternative subjective scoring - discriminates equally if not more. Overall, there is ample evidence that women default less frequently on loans (Coval et al., 2000) possibly because they are more risk adverse. We thus include gender in our CSM. Note that for this as well as all other binary variables, coding the variable based on equation (4e) leads to a more precise measure than simply assigning values of 0 and 1 .

Region represents the area of the country where the borrower lives. As people of similar wealth tend to live in the same location (a suburb might attract richer residents and the 
resulting increase in housing and property prices make this suburb prohibitively expensive for poorer households), this geographic criterion can indicate a borrower's level of financial wealth. A typical proxy is an area's postal code but in Vietnam a postal code is not part of the address. Instead, we approximate the region with the branch where the loan is issued. According to the bank's policy, borrowers can only obtain loans from their local branches and branch location therefore coincides with the borrowers' residential area. The numerous branches were categorized based on their similarity in default rates and four categories finally emerged: the north, center, south (excluding Ho Chi Minh City) of the country, and Ho Chi Minh City. Note that with this coding, region might not only be a proxy for the borrower's wealth but also reflect the current credit assessment ability of the different branches. In our sample, it appears that borrowers from Ho Chi Minh City are the best borrowers and those from the center are the worst. This make sense since the average income per person in Ho Chi Minh City is highest, followed by the north and south, while the center is the poorest area in Vietnam with lowest average income per person (World Bank, 2004).

Time at present address represents the number of years that the borrowers have been living at their current address. Crook et al. (1992) find that default risk drops with an increase in this variable. In this sense, time at present address might be a proxy for the borrower's maturity, stability, or risk aversion. However, this relationship does not hold in Vietnam where default rates increase with the time at the present address. In Vietnam, people who acquire financial wealth tend to seek better living conditions. This often includes moving to a new home in a better area. Thus, changing address might be a signal that a borrower's financial wealth is high and/or improving rapidly. Under these conditions, he is better able to repay his loan.

Residential status indicates whether borrowers own their home, rent, or live with their parents. Ex ante, the relationship between residential status and default is unclear. On the one hand, residential status can indicate financial wealth in particular in the case of home ownership. On the other hand, residential status can indicate increased financial pressure on the borrower's income through insurance fees, taxes, or electricity cost. Crook et al. (1992) find that those who are most likely to default belong to the "other" category whereas borrowers living with their parents are least likely to default. We expect that this ranking will be different for our sample since the reasons of having a certain residential status in Vietnam are dissimilar from those in industrialized countries. Almost $90 \%$ of all borrowers own their homes. If this home is used a collateral, default rates are among the lowest whereas default rates are highest when this home is not used as collateral. This can be explained by the importance of owning a 
house in Vietnamese society, which leads to a strong aversion of many borrowers to loose their house.

Marital status can matter if it has an effect on the responsibility, reliability, or maturity of borrowers. In our sample, however, default rates are higher for married than single borrowers. This unexpected result could be due to the fact that marital status is related to age or number of dependants.

Number of dependants represents the number of people that the borrower has to support. Crook et al. (1992) separate this variable into two categories, the number of children and the number of other dependants. In this study, we measure the total number of dependants though this variable mostly reflects the number children. As the number of dependants increases, so does the pressure on the borrower's income due to higher expenses such as school fees. In Vietnam as in industrialized countries, the default rate increases steadily with the number of dependents. For example, moving from zero to three dependants quadruples the default risk from $1.1 \%$ to $4.3 \%$.

Home phone measures whether a customer has a home phone or not and can indicate that the bank can easier to keep contact with that borrower. As in Crook et al. (1992), not having a home phone is associated with a higher default risk.

Mobile phone is defined similarly to home phone. Due to its wide-spread use in industrialized countries, this variable does not occur in credit scoring models for these countries. However, in Vietnam, having a mobile phone is still a good indication of the financial wealth. This fact may disappear in some years as the use of mobile phones spreads. Currently less than $30 \%$ of the bank's borrowers have a mobile phone and mobile phone is associated with a much lower default risk.

As the first two variables that measure the borrower's banking relationship, loan purpose describes the reasons why the borrower needs a loan and how the funds are used and collateral type measures what type of collateral supports the loan. Collateral type is a unique variable that is not incorporated in CSMs for industrialized countries. For microfinance in developing countries, Schreiner (1999) has a similar variable measuring the guarantee type (none, personal, multiple, other guarantee) for Bolivia and Viganó includes dummies for pledges, sales or personal guarantees for Burkina Faso. In our sample there is clear pattern between loan type and collateral type, partly due to the overlapping variable definitions. As such, both variables will be discussed together: Generally speaking, in the retail loan sector, requiring collateral is a signal of risk. Most defaults occur in the collateralized or business loan class. For business loans, $97.52 \%$ are supported by real estate as collateral, $1.4 \%$ by fixed asset 
collateral such as machines, $0.49 \%$ with mobile asset collateral and $0.06 \%$ with other collateral. Only $0.53 \%$ of business loans are not collateralized. At the other end of the distribution, credit cards do not require collateral and default rates are low. This can be explained by the fact that credit cards are still very new product, which is offered only to those borrowers who have close and good relationships with the bank. The exemptions to the rule are housing loans. Though for about $75 \%$ of these loans the house serves as collateral, less then $1 \%$ of these loans are in default. This might indicate borrowers' risk aversion regarding the loss of their house. This is consistent with culture and reality in Vietnam where people consider their houses as a very important feature of their life. - Furthermore, there is an overlap between the collateral type and residential status as only borrowers who live in their own home can use this as collateral. Note however that many borrowers who own more than one property, use a property that they do not live in as collateral for a (business) loan. This could again be a strong signal for the cultural importance of owning your home.

Collateral value reflects the value of collateral in millions of VND. This variable has not been used as a predictor in any CSM. In Vietnam's developing banking market, almost every loan requires collateral. The higher its value, higher the incentive for the borrower to repay as she does not want to loose her collateral. Furthermore, the value of collateral might be a proxy for the borrower's financial wealth since is has a significantly positive correlation with the borrower's income (0.25) and with the loan line (0.42).

Loan duration measures the maturity of loans in months. Usually, this is a feature of the loan and as such the outcome of the negotiation between borrower and bank. Whereas a borrower might be rejected for a shorter loan, she might be accepted for a longer one of the same size as the pressure on the borrower's income is now reduced. Thus, this variable is usually excluded from CSMs. However, the Vietnamese situation is different. What we measure here is the loan duration as proposed by the borrower and not as negotiated between the bank and borrower. Thus, this variable reflects the borrower's intention, risk aversion, or self-assessment of repayment ability.

Time with bank measures the length of the banking relationship in years. In the context of relationship lending, it can be assumed that the longer a customer stays with a bank, the more the bank knows about him and the lower the default risk becomes. Whereas this is confirmed for industrialized countries (Crook et al., 1992), it does not quite hold in Vietnam. The highest default rate can be found for those borrowers who have been with bank for 13 to 36 years whereas borrowers who have been with bank both shorter and longer are less likely to default. This could reflect the fact that the banking market is still under reform in Vietnam and 
that at least in the medium term, credit officers have room for preferential credit allocation. A reform progresses and credit scoring systems are put in place, the effect of this variable is expected to change and should thus be updated regularly.

Number of loans counts the number of loans a customer has received during her whole relationship with the bank. Many borrowers have not only a sequence of historical loans but also have more than one loan at a time. As a defaulted borrower has difficulties in receiving a new loan, this proxy can be informative about default risk. As expected, default is least frequent for repeat borrowers. This variable thus reflects the difficulty for a defaulted borrower to obtain a further loan from the same bank.

Current account is a binary variable that indicates whether the borrower holds a current account. This variable is relevant because it partly represents the financial wealth of customers (Crook et al., 1992) and confirms another link between the customer and the bank. In our sample, borrowers who hold current accounts have indeed a lower default risk.

Savings account is defined along the same lines as current account and holders of savings accounts are expected to default less frequently. This expectation holds in our sample. Though it is clear that people might prefer to first use their savings and then start borrowing, there are still about $8 \%$ of borrowers who have a savings account. The possible reason is that their saving accounts have an insufficient balance or that their savings cannot be liquidated immediately without loss of interest income. Both reasons would make a loan the rational choice.

\subsection{Model estimation}

To estimate the credit scoring model, the forward stepwise method is used to select among the 22 variables. This method starts with a model without any independent variables and sequentially adds variables. At each step, the variable that leads to the greatest improvement in predictive accuracy - in terms of the highest score statistic conditional upon a significance level of less than $5 \%$ - is added. The process continues until no variable with a significance level of less than $5 \%$ can be found. Applying the forward stepwise method, 16 variables are included in the model. In order to make sure that those selected variables are the most powerful predictors, the backward stepwise method is conducted as well. Here the starting point is a model that contains all 22 variables. At each step, the method eliminates the weakest variable so that only the strongest predictors are kept for the final model. As expected, the backward stepwise ends up with exactly the same 16 variables chosen by forward stepwise method. These variables as well as their coefficients are shown in Table 5. The six remaining 
variables are excluded due to one of two reasons. First, they have insignificant coefficients and do not contribute to the explanation of the dependent variable's variance. Second, they are eliminated because of their correlation with included variables. Together with adding the most predictive variable to the model, at every step of the backward stepwise regression, the tolerance $\left(1-\mathrm{R}_{\mathrm{i}}{ }^{2}\right)$ of every excluded variable is calculated. Those variables with tolerances of less than $80 \%$ (i.e. $20 \%$ or more of the variance in the variable is explained by variation in the other variables) are considered for deletion. In the case of multicollinearity, the inclusion of all variables leads to inferior results in the hold-out sample.

[Insert Table 5 about here]

The most important predictor is time with bank, followed by gender, number of loans, and loan duration. Compared to Crook et al.'s (1992) CSM for the UK, six out of their 12 predictors are incorporated in our model. These are: time with bank (ranked number $1^{\text {st }}$ here versus $3^{\text {rd }}$ by Crook et al. $)$, region $\left(6^{\text {th }}\right.$ vs. $\left.1^{\text {st }}\right)$, current account $\left(8^{\text {th }}\right.$ vs. $\left.4^{\text {th }}\right)$, residential status $\left(7^{\text {th }}\right.$ vs. $\left.6^{\text {th }}\right)$, home phone $\left(14^{\text {th }}\right.$ vs. $\left.7^{\text {th }}\right)$, and savings account $\left(5^{\text {th }}\right.$ vs. $\left.9^{\text {th }}\right)$. Compared to Crook's longer list of 24 most typical variables there is an overlap with nine of our variables. As such, our model reflects - at least partly - the international norm of a credit scoring. The inclusion of variables such a collateral type, loan duration, or gender is however unique to developing countries. Regarding the accuracy of the model, the explanatory power of the model increase from step to step leading to a final adjusted R-square of 0.578 . However, to properly assess the accuracy of the model, it should be applied out-of-sample.

\subsection{Model calibration and out-of-sample testing}

When applied out-of-sample, we find as expected a significant difference in the predicted PD between observed defaulted and non-defaulted borrowers. The average (median) of the predicted PD is $1.73 \%(0.2 \%)$ for non-defaulted loans compared to $49.05 \%(51.66 \%)$ for defaulted loans. However, the ranges of predicted probabilities are rather large and overlap for the two loan groups. For defaulted loans PD ranges from $0.01 \%$ to $96.81 \%$ compared to $0.00 \%$ to $73.54 \%$ for non-defaulted loans. A closer look at Panel A of Table 6 reveals the observed versus predicted PD for different sub-samples which are generated by sorting all loans of similar predicted PD into five groups of approximately equal size. By looking at the average estimated PD of $3.33 \%$ compared to the observed PD of $3.19 \%$ we can see that our model slightly overestimates default. There is however a pattern. The PD of the low-risk groups 1 to 3 
are underestimated whereas the maximum estimated probability is far beyond the observed PD. The average predicted PDs indicate that default risk is rising steadily but only jumps above the $1 \%$ level for group 5. A more detailed accuracy analysis is thus warranted using the PCC, SENS, and SPEC indicators.

[Insert Table 6 about here]

Panel B of Table 6 reports the accuracy measures PCC, SENS, and SPEC when imposing an ad-hoc cut-off value of 50\%. Regarding PCC, the overall accuracy is surprisingly high with almost 99\%. Looking at defaulted versus non-defaulted loan separately reveals that this high accuracy is mainly driven by the non-defaulted loans as $\mathrm{PCC}_{\text {good }}(99.55 \%)$ is much higher than $\mathrm{PCC}_{\mathrm{bad}}(50.25 \%)$. Compared to studies for industrialized countries, Desai et al. (1996) report accuracy values of up to $86.90 \%$ for $\mathrm{PCC}_{\text {total }}$ and $41.38 \%$ for $\mathrm{PCC}_{\mathrm{bad}}$. For Bolivia, Schreiner's (1999) calibrations are able to achieve a maximum accuracy for $\mathrm{PCC}_{\text {total }}$ of $91 \%, \mathrm{PCC}_{\mathrm{good}}$ of $99 \%$, and $\mathrm{PCC}_{\mathrm{bad}}$ of $71 \%$. Overall, our results are in line with these findings. ${ }^{10}$ The sensitivity measure implies a PD for the bank's loan portfolio of $(100 \%$ - SENS $)=1.62 \%$ because all applicants with a predicted PD of less than 50\% will be accepted and $98.38 \%$ of these are expected to repay the loan. Our SENS accuracy is slightly higher than that reported in other studies. For example, Baesens et al.'s (2003) survey reports sensitivity measures of up to $96.36 \%$. Finally, the specificity of the model implies that among the rejected loan applications (predicted PD $>50 \%$ ), $78.63 \%$ of them would have actually defaulted whereas $21.37 \%$ would have been repaid. Note that SPEC is actually an abstract measure since in practice a bank cannot check whether its rejected loan applicants would have defaulted or not. These $21.37 \%$ incorrectly rejected loans should be interpreted as opportunity cost for the bank. In contrast, the $1.62 \%$ of incorrectly accepted loans creates actual cost for the bank.

The calibration of the model, i.e. the determination of the optimal cut-off, depends on the preferences of the bank. The bank from which we obtained the loan data has no CSM in place that predicts default but is relying on subjective credit assessment. It has however set a target for non-performing loans. Assume that our bank's target is $0.83 \%$. With such a target in mind, we have to calibrate the CSM to a sensitivity of $99.17 \%$ (SENS $=100 \%-0.83 \%=$ 99.17\%). At the first sight, one might think that in order to achieve this target, bank should only accept customers who have predicted PD of less than $0.83 \%$. Such a cut-off would however lead to a SENS of $99.33 \%$ and thus an expected PD of $0.77 \%$. Instead, a cut-off of

\footnotetext{
${ }^{10}$ See footnote 8 .
} 
$19.95 \%$ as shown in Panel $\mathrm{C}$ of Table 6 would achieve the desired result. Comparing the accuracy of this cut-off with that of the ad-hoc cut-off of 50\% reveals the following dynamics: By sacrificing a small amount of good loans ( $\mathrm{PCC}_{\mathrm{good}}$ drops from $99.55 \%$ to $97.74 \%$ ), the number of incorrectly accepted bad loans increases substantially ( $\mathrm{PCC}_{\mathrm{bad}}$ increases from $50.25 \%$ to $75.06 \%$ ). In terms of SENS and SPEC, the improvement by $0.79 \%$ in sensitivity is achieved at a cost of a $26.36 \%$ reduction in specificity.

\section{Credit scoring and bank strategy}

In the previous section, the cut-off value of $19.95 \%$ was chosen for the bank to achieve its default target of $0.83 \%$. However, is that the optimal cut-off value for the bank if it follows other strategies such as minimizing the time spent on credit assessment or return maximization? In order to answer this question, we go to look at alternative ways to calibrate the CSM.

\subsection{Profitability}

For a commercial bank, the benefit of implementing a CSM can lie in the effect that the new credit assessment policy has on the bank's profitability. Schreiner (2003) suggests measuring the change in profits in terms of opportunity cost. In particular he focuses on the ratio of good loans lost $\left(\mathrm{G}_{\mathrm{b}}\right)$ per bad loans avoided $\left(\mathrm{B}_{\mathrm{b}}\right)$. In the context of the accuracy criteria introduced above, this measure is to some extend related to the SPEC measure. Panel A of Figure 2 shows how this ratio changes for different cut-off values and Panel B calculates the effect on profit as

$\Delta$ profit $=$ cost per bad loan $* \mathrm{~B}_{\mathrm{b}}-$ benefit per good loan $* \mathrm{G}_{\mathrm{b}}$

For the cut-off of $19.95 \%$ identified as optimal in the previous section, the tradeoff is foregoing 0.91 good loans for each bad loan that is avoided. In terms of profit changes, we assume different relationships between the cost per bad loan and benefit per good loan. Data for developing countries is not available but we can take the evidence from the credit card market in industrialized countries as a benchmark. Here, practitioners argue that it takes 10 good loans to cover the cost of one bad loan (Schreiner, 2003). Under this assumption, a cut-off of $19.95 \%$ leads to an increase in profits, which would indicate that our bank's target of $0.83 \%$ nonperforming loans is well set. Overall, however, the change in profits is relatively stable for a cut-offs of $7 \%$ to $20 \%$ before dropping off more substantially. A further look at Panel B 
reveals that as the cost-benefit ratio becomes smaller, so does the effect on profits. With a costbenefit ratio of 10 to 5 , an increase in profits can only be obtained with cut-off value of $7 \%$ or higher.

[Insert Figure 2 about here]

\subsection{Risk-based pricing}

Economic theory suggests that in a competitive market, prices will equal marginal cost. If the market price is higher, the high profit margin will induce competitors to enter the market and bid down the price. This principle implies that each loan should be priced in accordance with cost of funds, origination and servicing costs, and the implicit costs associated with potential default. While the fixed costs do not generally vary within the same product category, costs associated with default risk can vary across borrowers and should be calculated as PD times loss given default (LGD). The risk-based interest rate on a loan $\mathrm{R}$ could thus be derived in a simple model as

$\mathrm{R}=$ cost of funds + overhead cost + expected default cost + profit margin

As Vietnam moves towards a more and more competitive retail banking market, borrowers will shop around and any bank offering too high interest rates for good borrowers will loose market share. At the same time, banks offering too low interest rates for bad borrowers will experience eroding profits. Risk-based pricing therefore seems to be necessary if a bank wants to survive in Vietnam's emerging banking market. Currently, however, our bank charges the same annual interest rate for all medium- and long-term loans. Based on our CSM, we can suggest a simple pricing strategy.

As Table 7 shows, we split the bank's borrowers into three risk classes containing about 7,500 borrowers each. The predicted PD for the low risk class ranges from $0.00 \%$ to $0.04 \%$, for the moderate risk class from $0.05 \%$ to $0.30 \%$, and for the high risk class from $0.31 \%$ to $19.95 \%$. Given the targeted maximum of $0.83 \%$ non-performing loans, any applicant with an estimated PD of more than $19.95 \%$ will be rejected. Based on our discussions with Vietnamese bankers, a $2.00 \%$ profit margin and an average $1.50 \%$ overhead cost appear to be reasonable and realistic assumptions. However, customers with higher risk usually create higher costs because they take more of the credit officer's time. To be consistent with customer-specific pricing, overhead cost of $2.00 \%, 1.50 \%$, and $1.00 \%$ will be allocated to the 
high-, moderate-, and low-risk borrowers, respectively. The cost of funds can be approximated by the bank's deposit interest rate. In Vietnam, the annual deposit interest rate on local currency deposits is currently about $9 \%$. Finally, the expected cost of default has to be considered. This cost can be calculated as PD*LGD. Our CSM provides estimates for PD but it is beyond the scope of this study to estimate LGD. LGD will be at least loan-type specific since each type of loan is associated with a different type of collateral. Default cost can be quite significant. As a benchmark note that in 1997 risk-premia for US consumer loans ranged from as low as $0.10 \%$ to more than $2.00 \%$ for the highest risk borrowers (Sangha, 1998). In line with this study, we decided to assign $2.00 \%$ default cost to the high-risk borrowers, $0.20 \%$ to the moderate-risk and $0.10 \%$ to the low-risk borrowers. As Table 7 shows, the bank could charge $12.10 \%, 12.70 \%$, and $15.00 \%$ to the different risk classes. If, on the other hand, the banks decide to charge the same price to all borrowers, it could charge an average interest rate of approximately $13.30 \%$ to earn the same profit margin. As the second set of calculations shows, these assumptions would be consistent with a LGD of $100 \%$ and a PD based on the realized PD of the risk class. In practice, PD could be based on the historic PD obtain from the loan portfolio which is used when estimating the CSM.

[Insert Table 7 about here]

\subsection{Transactional versus relationship lending}

Should banks rely exclusively on their CSM, i.e. transactional lending, or should there be room for relationship lending? The benefits of credit scoring are clear. Mester (1997), for example, reports that credit scoring has substantially reduced the length of the loan approval process from two weeks to 12.5 hours for small-business loans in the US, or from nine to three days for consumer loans in Canada. Once a CSM is in place, these benefits can be achieved at a cost of $\$ 1.50$ to $\$ 10$ per loan. In order to reduce the cost, time, and effort that credit officers spend on loan assessment or to allocate the officers time more productively, banks might thus be inclined to implement a strict credit policy based on their CSM alone. In industrialized countries, internet banks rely on automated loan systems which include CSMs. Mester (1997) reports that Banc One exclusively uses credit scores for loans up to $\$ 35,000$ and approves a further 30\% of all loans below \$ 1 million only based on scores. Furthermore, a regional bank in Pennsylvania assesses all small business loans under \$ 35,000 based on the CSM alone. The downside, however, can be substantial. Schreiner (2003) recalls a Bolivian example of a finance company that relied exclusively on its CSM and went bankrupt. 
Credit scoring is based on quantifiable criteria and ignores qualitative risk. Its underlying assumption is that qualitative risk is either irrelevant or not measurable. Is this assumption reasonable? If qualitative risks matter but are not captured indirectly via the quantitative variables in the model, the estimated PD will be too low. ${ }^{11}$ To the extent that credit officers can discover this qualitative risk through their relationship with the borrower, a combination between transactional and relationship lending is valuable. Most banks in industrialized countries therefore rely on such a combination. Credit scoring can either precede or follow traditional loan assessment. On the one hand, Schreiner (2003) argues that banks should apply their CSM only to loans that are already conditionally approved by the credit officer. On the other hand, Mester (1997) reports that banks in the US have credit officers reviewing the CSM's decision and that many banks focus on those loan applicants with scores close to the cut-off point. For the First National Bank of Chicago this led to a substantial change in the credit decisions for small-business loans. About $25 \%$ of the applications rejected by the model were later approved by the credit officer and another $25 \%$ of the applications accepted by the model were later rejected by the credit officer. Based on our hold-out sample, we can only illustrate this second approach. ${ }^{12}$ In particular, we will illustrate how a CSM can be calibrated for several rather than just one cut-off point. We suggest two cut-offs $C_{1}$ and $C_{2}$ with $0<\mathrm{C}_{1}<\mathrm{C}_{2}<1$. Such a calibration allows banks to define loans that need some further examinations instead of rejecting or accepting them directly. All loan applicants with an estimated $\mathrm{PD}<\mathrm{C}_{1}$ are accepted outright whereas all applicants with $\mathrm{PD}>\mathrm{C}_{2}$ are rejected outright. The remaining loans with $\left(\mathrm{C}_{1}<\mathrm{PD}<\mathrm{C}_{2}\right)$ are classified as marginal loans which are consequently reviewed by the credit officer. The bank's credit assessment can thus be a combination of the transactional lending via CSM and relationship lending.

Panel D of Table 6 reports the results of such a CSM. $\mathrm{C}_{1}$ and $\mathrm{C}_{2}$ are determined according to a somewhat arbitrary decision rule which can be interpreted in the context of PCC. This rule specifies that (1) the proportion of incorrectly classified bad loans should be less than $5 \%$ of all bad loans, i.e. $\mathrm{B}_{\mathrm{g}} / \mathrm{B}<5 \%$, and (2) that the proportion of correctly classified bad loans should be at least $75 \%$ of all bad loans, i.e. $B_{b} / B \geq 75 \%$. The emphasis on bad loans is justified by the relatively high penalty costs associated with over looking a potentially bad loan. The trade off for this cost is the gain from reducing the number of good loans subjected to evaluation. If those evaluation costs were available, $C_{1}$ and $C_{2}$ can be determined so that total evaluation cost is minimized. For an even more advanced approach, evaluation cost can

\footnotetext{
${ }^{11}$ See Schreiner (2003), Box 4 for a more in-depth discussion.

${ }^{12}$ Note however that Schreiner's approach is to some extend implicit in our sample as it is restricted to approved loans and does not cover all loan applications.
} 
be included in the model presented in section 4.1. and $\mathrm{C}_{1}$ and $\mathrm{C}_{2}$ can be chosen based on a profit maximization rule. However, since these costs have not yet been precisely estimated by our bank, the above decision rule has been applied resulting in the cut-off points $\mathrm{C}_{1}=1 \%$ and $\mathrm{C}_{2}=21 \%$.

The model predicts 19,063 good, 4,836 marginal and 1,141 bad loans. Regarding the actual bad loans, 40 were classified as good, 155 as marginal and 603 as bad. The implication for credit assessment is that the 40 loans will not be evaluated by the credit officer but incorrectly accepted outright. The 155 loans will be examined together with the 4,681 other marginal loans. If the credit officer can correctly spot these 155 loans, the bank would reject 758 of the 798 actual bad loans. In contrast, the CSM with a single cut-off of $19.95 \%(50 \%)$ leads to a rejection of only 599 (401) of the observed bad loans. Regarding the observed good loans, our two cut-off points do not lead to any substantial change compared to the models with one cut-off point. This is due to the criteria imposed on the cut-off points. Assuming again that the credit officer can correctly spot the 4,681 observed good loans among the marginal loans, the bank would accept 23,704 of the 24,245 observed good loans. In comparison, the model with one cut-off at $19.95 \%(50 \%)$ achieves a correct prediction of $23,698(24,136)$ loans.

\section{Conclusions}

As banking markets in developing countries are maturing, banks face competition not only from other domestic banks but also from sophisticated foreign banks. Combined with a dramatic growth of retail credit and increased regulatory attention on risk management, the development of a well-functioning credit assessment framework is essential. As part of such a framework, we develop a CSM for Vietnamese retail loans. Though many of the borrower characteristics relevant for the credit decision are the same as in developed countries, they show different relationships with default risk and as such reveal economic and cultural aspects that are unique to Vietnam as a developing country. While we investigate special features of the CMS related to a bank's strategy in terms of profitability or risk-based pricing and discuss the role of relationship versus transactional lending, some aspects of credits scoring remain unexplored. In this study, we only provide a single estimation of the CSM. In practice, however, banks need to update their CSM on a regular basis. For developing countries where economic changes are more pronounced than in the relatively stable developed countries, it would be interesting to investigate how stable a CSM is over time. It might turn out that a regular update of its CSM is even more important for a bank in a developing than in a 
developed country. Furthermore, it might be interesting to compare CSM of banking markets that are in various stages of development. In this way one could explore any linkages that exist between the features that determine loan default, i.e. the variables included in the CSM and their relative importance, and financial and economic development.

\section{References}

Allen, L., DeLong, G., Saunders, A. (2004). Issues in credit risk modeling of retail markets. Journal of Banking and Finance 28, 727-752.

Altman, E.I. (1968). Financial ratios, discriminant analysis, and the prediction of corporate bankruptcy. Journal of Finance 23, 589-609.

Boyle, M., Crook, J.N., Hamilton, R., Thomas, L.C. (1992) Method s for credit scoring applied to slow payers. In: Thomas, L.C., Crook, J.N., Edelman, D.B. (Eds), Credit scoring and credit control, Oxford University Press, Oxford, 75-90.

Baesens, B., Gestel, T.V., Viaene, S., Stepanova, M., Suykens J., Vanthienen, J. (2003). Benchmarking state-of-the-art classification algorithms for credit scoring. Journal of the Operational Research Society 54, 627-635.

Coval, J., Shumway, T. (2000). Do behavioral biases affect prices? University of Michigan, Working Paper.

Crook, J.N., Hamilton, R., Thomas, L.C. (1992). A comparison of discriminations under alternative definitions of credit default. In: Thomas, L.C., Crook, J.N., Edelman, D.B. (Eds), Credit scoring and credit control, Oxford University Press, Oxford, 217-245.

Desai, V.S., Crook, J.N, Overstreet, G.A. (1996). A comparison of neutral networks and linear scoring models in the credit union environment. European Journal of Operational Research 95, 24-37.

Desai, V.S., Crook, J.N, Overstreet, G.A. (1997). Credit scoring models in the credit union environment using neutral networks and genetic algorithms. IMA Journal of Mathematics Applied in Business and Industry 8, 323-346.

Henley, W.E., Hand, D.J. (1997). Statistical classification methods in consumer credit scoring: a review. Journal of the Royal Statistical Society - Series A (Statistics in Society) 160, $523-541$.

Henley, W.E. (1995). Statistical aspects of credit scoring. Open University, Dissertation. 
Loi H.T. (2004). Trends and developments in insolvency system and risk management - the experience of Vietnam. Presentation given at a forum on Asia's insolvency reform in 2004.

Mester, L. (1997). What's the point of credit scoring? Federal Reserve Bank of Philadelphia Business Review, September/October, 3-16.

Miller, M., Rojas, D. (2004). Improving access to credit for SMEs: An empirical analysis of the viability of pooled data SME credit scoring models in Brazil, Colombia \& Mexico. Working paper available at http://siteresources.worldbank.org/INTFR/Resources/ 475459-1107891190953/661910-1108584820141/Miller_ImprovingAccesstoCredit.pdf Nguyen, N.X., 2004. Country report Vietnam. Paper presented at The Japan Institute for Labour Policy and Training's 2004 workshop on 'International Migration and Labour Market in Asia', available at http:/www.jil.go.jp/foreign/event_r/event/documents/ 2004sopemi/2004sopemi_e_countryreport12.pdf.

Provost, F., T. Fawcett, and R. Kohavi (1998). The case against accuracy estimation for comparing classifiers. Proceedings of the Fifteenth International Conference on Machine Learning, 445-553.

Srinivasan, V., Kim, Y.H. (1987). The Bierman-Hausman credit granting model: A note. Management Science 33, 1361-1362.

Sangha, B.S. (1998). A systematic approach for managing credit score overrides. In: Mays, E. (Ed), Credit risk modeling design and application, Glenlake Publishing, Chicago, 223244.

Schreiner, M. (1999). A scoring model of the risk of costly arrears at a microfinance lender in Bolivia. Working paper available at ftp://econwpa.wustl.edu/econ-wp/dev/papers/0109/ 0109005.pdf

Schreiner, M. (2003). Scoring: The next breakthrough in microcredit? CGAP Occasional Paper No. 7, available at http://www.cgap.org.

Thomas L.C. (2000). A survey of credit and behavioral scoring: Forecasting financial risk of lending to consumers. International Journal of Forecasting 16, 149-172.

Viganó, L. (1993). A credit scoring model for development banks: An African case study. Savings and Development 4, 441-482.

Yobas, M.B., Crook, J.N., Ross, P. (1997). Credit scoring using neural and evolutionary techniques. Credit Research Center, University of Edinburgh, Working Paper 97/2. 
Figure 1

Coding quantitative variables when the relationship to default is non-linear

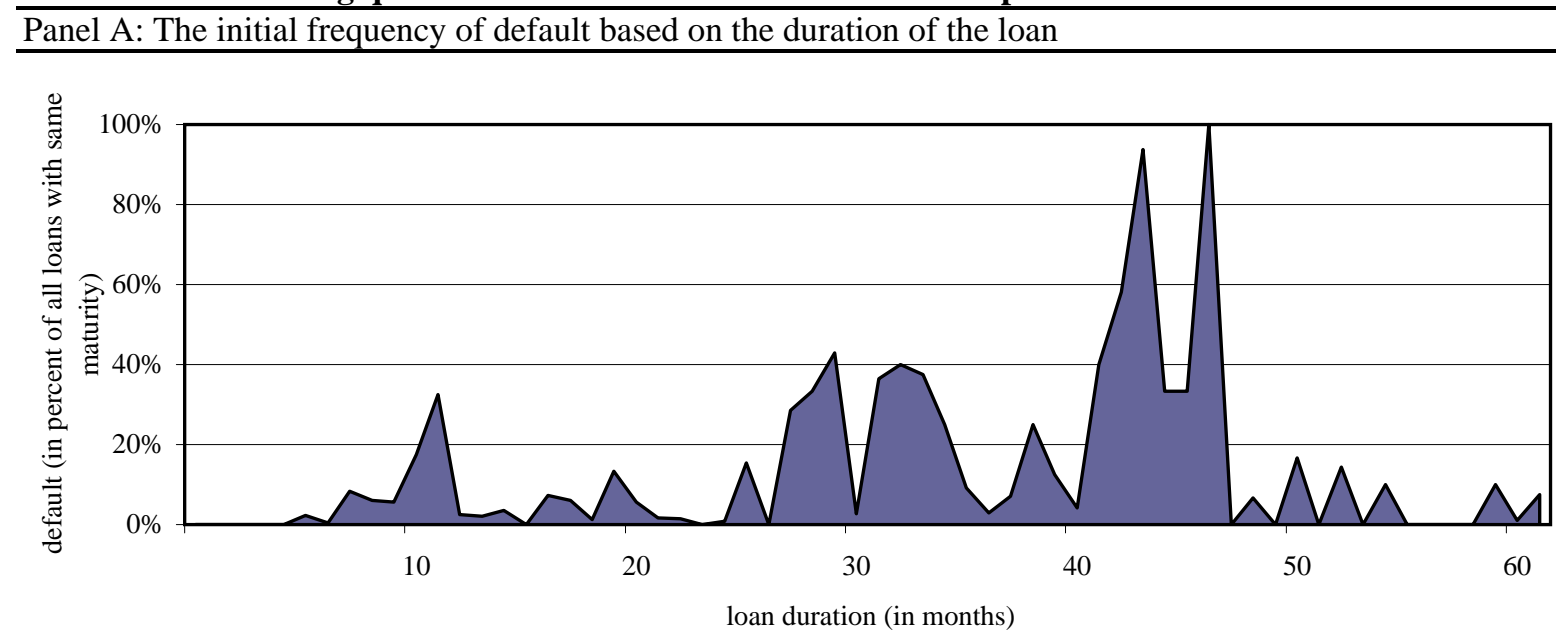

Panel B: The categorized frequency of default based on the duration of the loan

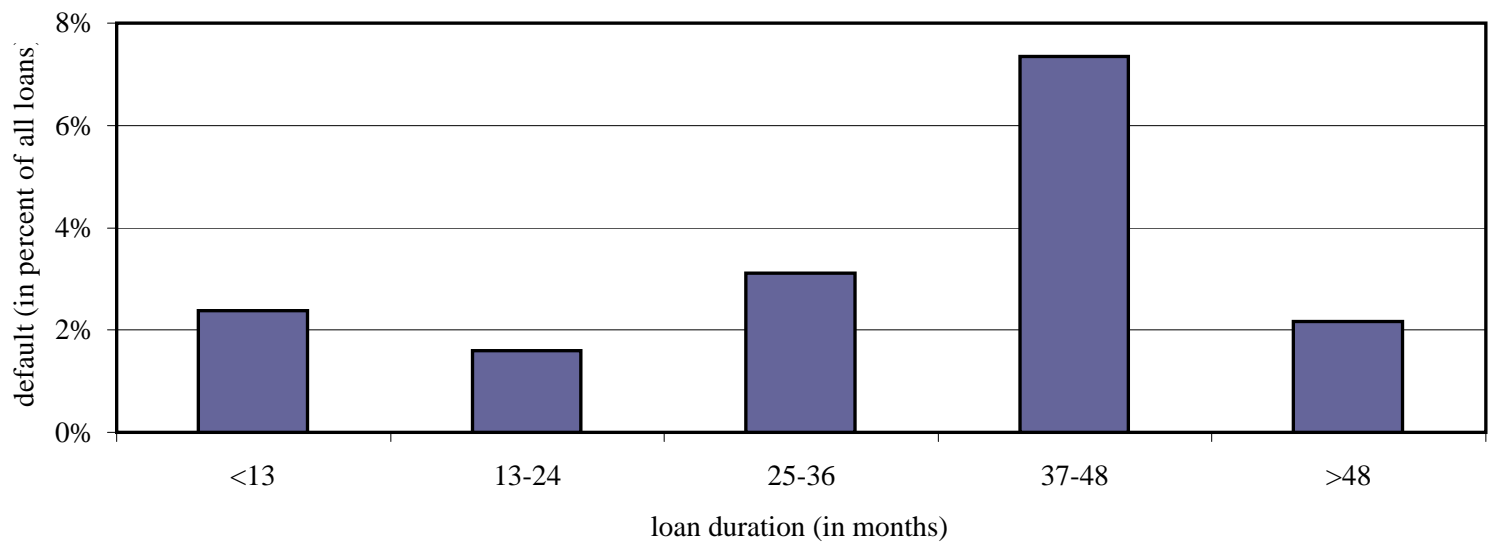

Panel C: The relationship between default and duration after coding

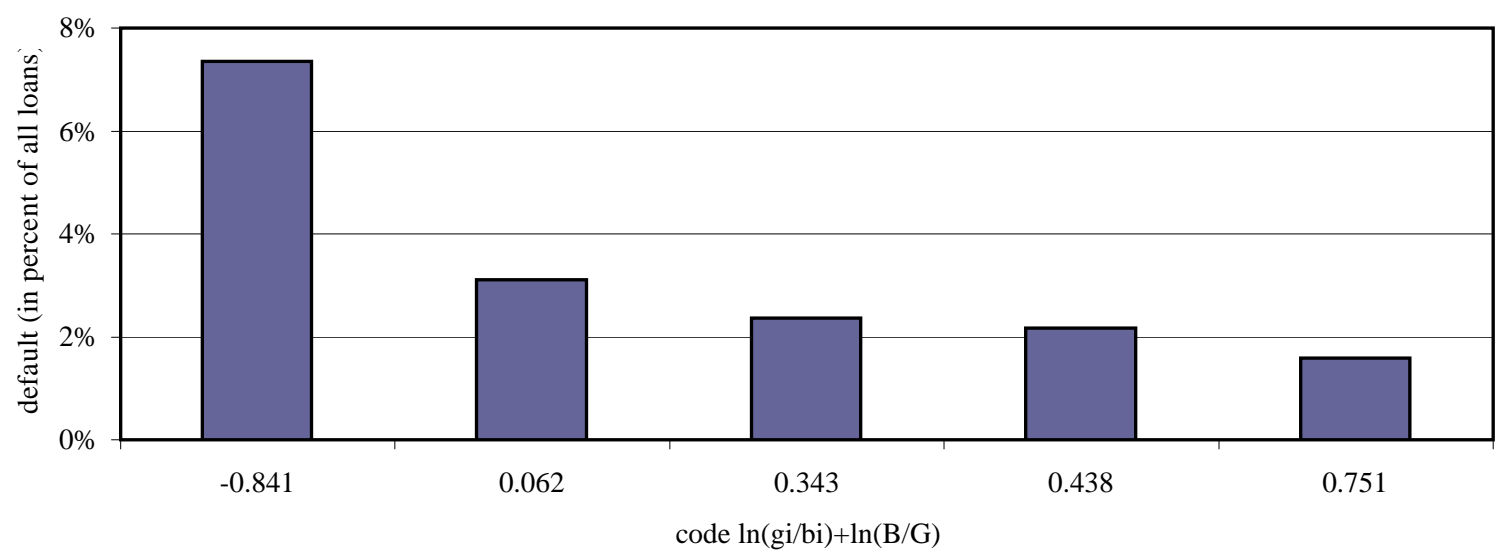


Figure 2

Credit scoring and bank profitability

Panel A: Opportunity cost as good loans lost per bad loans avoided

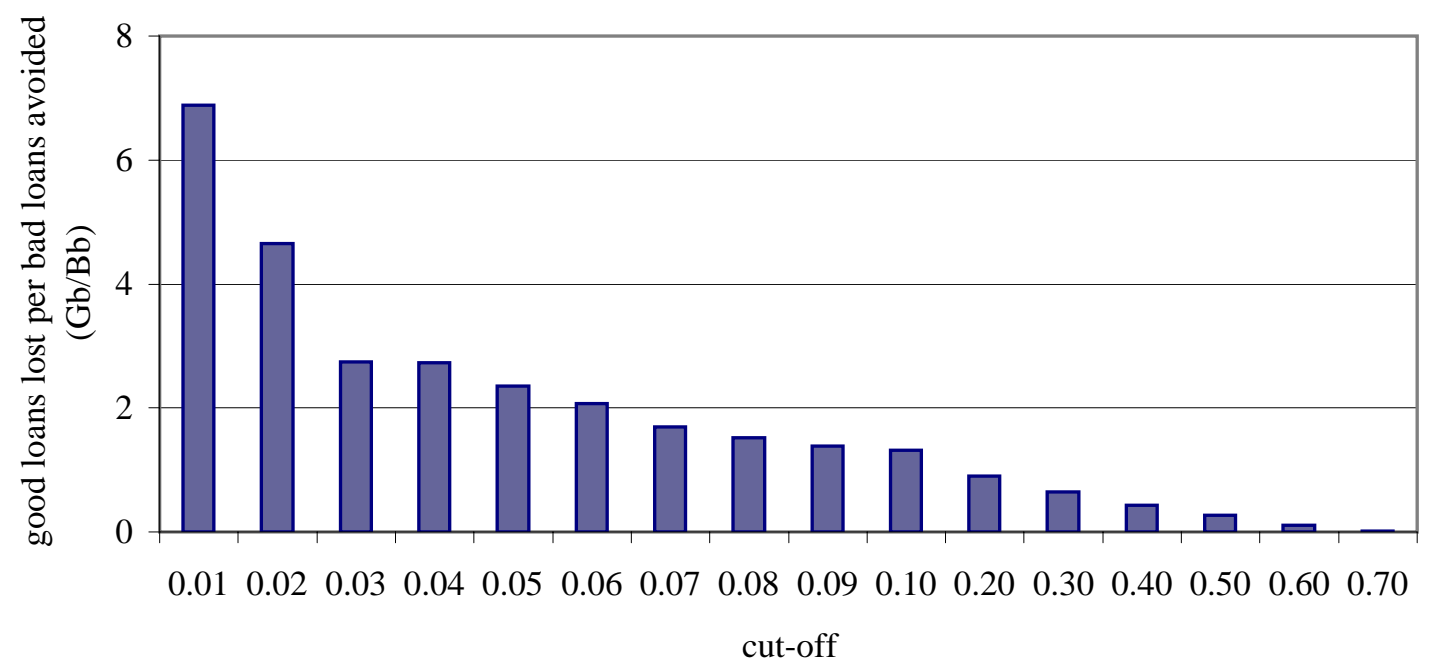

Panel B: Change in profit

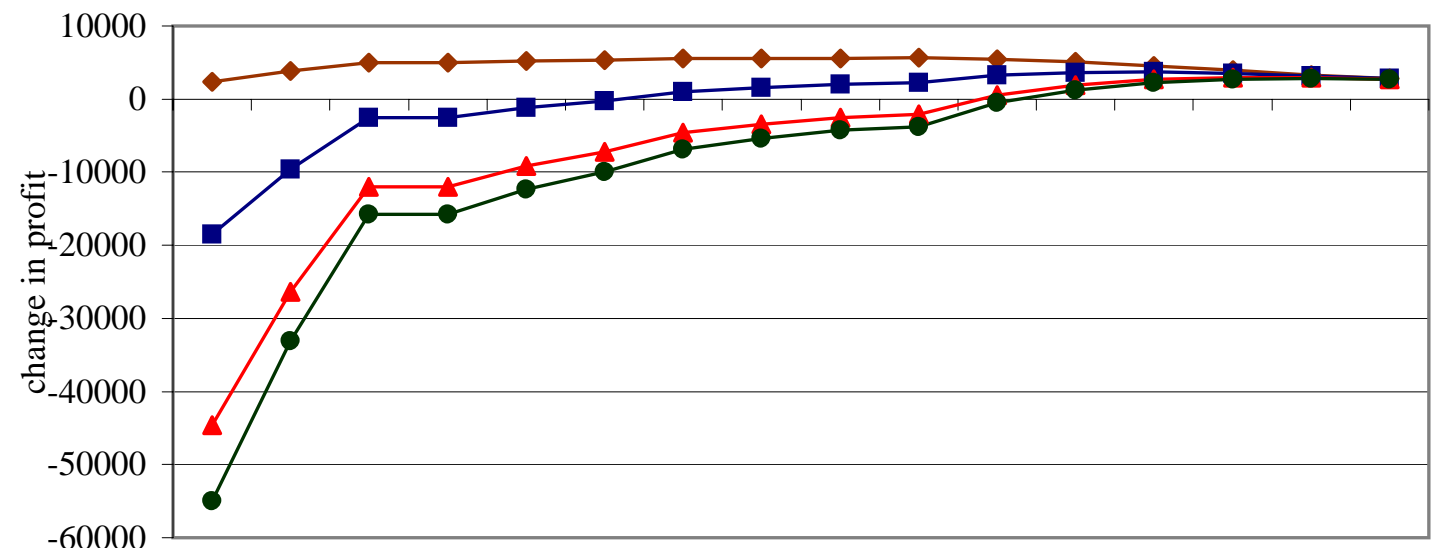

$\begin{array}{llllllllllllllll}0.01 & 0.02 & 0.03 & 0.04 & 0.05 & 0.06 & 0.07 & 0.08 & 0.09 & 0.10 & 0.20 & 0.30 & 0.40 & 0.50 & 0.60 & 0.70\end{array}$

cut-off

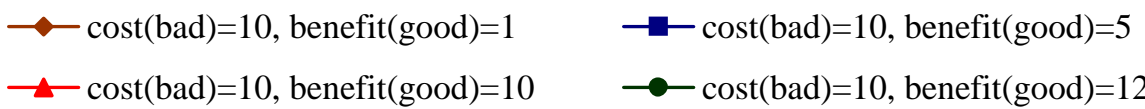


Table 1

Variables commonly used in retail credit scoring models

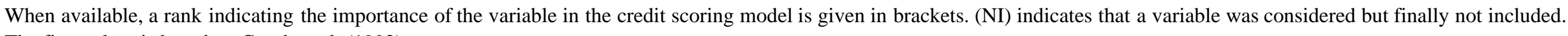
The first colum is based on Crook et al. (1992).

commonly used variables in industrialized countries

Postcode

Age

Number of children

Number of other dependants

Whether an applicants has a home phone

Spouse's income

Employment status

Employment category

Years at present employment

Income

Residential status

Years at present address

Estimated value of home

Mortgage balance outstanding

Years at bank

Whether a current account is held

Whether a deposit account is held

Whether a loan account is held

Whether a check guarantee card is held

Whether a major credit card is held

Whether a charge card is held

Whether a store card is held

Whether a building society card is held

variables included in the credit scoring model

Crook et al. (1992) - UK

Schreiner (1999) - Bolivia

Date of disbursement

Employment status (2) $\quad$ Amount disbursed

Years at bank (3) Type of guarantee

Branch

Current account (4)

Spouse's income (5)

Residential status (6)

Phone (7)

Years at present employment (8)

Deposit account (9)

Value of home (10)

Outgoings (11)

Number of children (12)

Applicant's income (NI)

Mortgage balance outstanding (NI)

Charge card (NI)

Loan officer

Gender of the borrower

Sector of the firm

Number of spells or arrears

Length of the longest spell of arrears

(193) - Burkina Faso

Customer's personal characteristics

(age, sex, religion, martial status, education,

employment sector and place, etc)

Data on the enterprise

(type, professional skills, number of employees,

productivity, profitability, etc)

Profitability

(main and secondary revenue, revenue stability)

Amount and composition of assets

(total assets including money and deposits)

Financial situation

(initial and current amount of loans received,

defaults, loans granted)

Investment plans

(presence of investment plan, other sources of finance)

Customer's relationship with bank

(past loans with bank, savings account with

bank, etc)

Bank's control of credit risk

(loan distination, disbursement form, method

of repayment, loan amount and maturity, collateral,

contractual conditions on interest rate, etc)

Value of outgoings 
Table 2

Predictive accuracy of credit scoring models

\begin{tabular}{|c|c|c|c|}
\hline \multirow[b]{2}{*}{ observation } & \multicolumn{2}{|c|}{ prediction } & \multirow[b]{2}{*}{ PCC } \\
\hline & non-default & default & \\
\hline non-default & $\mathrm{G}_{\mathrm{g}}$ & $\mathrm{G}_{\mathrm{b}}$ & PCC $_{\text {good }}=G_{g} /\left(G_{g}+G_{b}\right)$ \\
\hline default & $\mathrm{B}_{\mathrm{g}}$ & $\mathrm{B}_{\mathrm{b}}$ & $\mathrm{PCC}_{\mathrm{bad}}=\mathrm{B}_{\mathrm{b}} /\left(\mathrm{B}_{\mathrm{b}}+\mathrm{B}_{\mathrm{g}}\right)$ \\
\hline & & & PCC $_{\text {total }}=\left(\mathrm{G}_{\mathrm{g}}+\mathrm{B}_{\mathrm{b}}\right) /\left(\mathrm{G}_{\mathrm{g}}+\mathrm{G}_{\mathrm{b}}+\mathrm{B}_{\mathrm{b}}+\mathrm{B}_{\mathrm{g}}\right)$ \\
\hline SENS & $\mathrm{G}_{\mathrm{g}} /\left(\mathrm{G}_{\mathrm{g}}+\mathrm{B}_{\mathrm{g}}\right)$ & & \\
\hline SPEC & & $3_{b} /\left(B_{b}+G_{b}\right)$ & \\
\hline
\end{tabular}


Table 3

An example of credit assessment in Vietnam

\section{Panel A: Variables considered in the first round of credit assessment}

$\underline{\text { variable }} \quad \underline{\text { categories }}$

age

education

occupation

total time in employment

time in current job

residential status

number of dependents

applicant's annual income

family's annual income
18-25, 26-40, 41-60, >60 (years)

post graduate, graduate, high school, less than high school

professional, secretary, businessman, pensioner

$<0.5,0.5-1,1-5,>5$ (years)

$<0.5,0.5-1,1-5,>5$ (years)

Owns home, rents, lives with parents, other

0, 1-3, 3-5, >5 (people)

$<12,12-36,36-120,>120$ (million VND)

$<24,24-72,72-240,>240$ (million VND)

\section{Panel B: Variables considered in the second round of credit assessment}

\section{variable}

performance history with bank (short-term)

performance history with bank (long-term)

total outstanding loan value

other services used

average balance in saving account during previous year categories

new customer, never delaid, payment delay less than 30 days, payment delay more than 30 days new customer, never delaid, delay during 2 recent years, delay earlier than 2 recent years

$<100,100-500,500-1000$, >1000 (million VND)

savings account, credit card, savings account and credit card, none

$<20,20-100,100-500,>500$ (million VND)

\section{Panel C: Loan decision}

applicant's rating
Aaa
$\mathrm{Aa}$
$\mathrm{a}$
$\mathrm{Bbb}$
$\mathrm{Bb}$
$\mathrm{b}$
$\mathrm{CcC}$
$\mathrm{Cc}$
$\mathrm{C}$
$\mathrm{d}$

score
$>=400$
$351-400$
$301-350$
$251-300$
$201-250$
$151-200$
$101-150$
$51-100$
$0-50$
0

$\underline{\text { loan decision }}$

lend as much as requested by borrower lend as much as requested by borrower

lend as much as requested by borrower loan amount depends on the type of collateral

loan amount depend on the type of collateral with assessment

loan application requires further assessment

reject loan application

reject loan application

reject loan application

reject loan application 
Table 4

Variables included in the Vietnamese retail credit scoring model

\begin{tabular}{|c|c|c|}
\hline variables & categories & default \\
\hline income & $(0.5-1.5)$ & $7.93 \%$ \\
\hline \multirow[t]{4}{*}{ (in million VND per month) } & $(1.5-3.5)$ & $1.51 \%$ \\
\hline & $(3.5-8.0)$ & $0.29 \%$ \\
\hline & $(>8.0)$ & $0.13 \%$ \\
\hline & other & $4.07 \%$ \\
\hline \multirow[t]{6}{*}{ education } & post graduate & $0.30 \%$ \\
\hline & university graduate & $1.23 \%$ \\
\hline & college graduate & $9.02 \%$ \\
\hline & high school graduate & $2.40 \%$ \\
\hline & non-high school graduate & $3.96 \%$ \\
\hline & other & $1.48 \%$ \\
\hline \multirow[t]{5}{*}{ occupation } & farmer, housewife, student & $3.37 \%$ \\
\hline & entrepreneur, farm owner, consultant/broker & $0.23 \%$ \\
\hline & doctor, professional, researcher, lawyer, teacher & $1.90 \%$ \\
\hline & police, military, journalist & $6.07 \%$ \\
\hline & other & $0.85 \%$ \\
\hline \multirow[t]{4}{*}{ employer type } & self-employed (entrepreneur) & $0.22 \%$ \\
\hline & joint-venture, foreign & $0.22 \%$ \\
\hline & joint-stock, state-owned & $1.06 \%$ \\
\hline & other & $3.98 \%$ \\
\hline time with employer & $(0-2)$ & $2.31 \%$ \\
\hline \multirow[t]{4}{*}{ (in years) } & $(2-5)$ & $2.09 \%$ \\
\hline & $(5-10)$ & $2.72 \%$ \\
\hline & $(10-20)$ & $4.44 \%$ \\
\hline & $(20-35)$ & $3.37 \%$ \\
\hline age & $(18-24)$ & $1.98 \%$ \\
\hline \multirow[t]{4}{*}{ (in years) } & $(25-35)$ & $2.94 \%$ \\
\hline & $(36-45)$ & $3.27 \%$ \\
\hline & $(46-64)$ & $2.91 \%$ \\
\hline & $(>65)$ & $4.66 \%$ \\
\hline \multirow[t]{2}{*}{ gender } & male & $3.80 \%$ \\
\hline & female & $2.49 \%$ \\
\hline \multirow[t]{4}{*}{ region } & north & $0.32 \%$ \\
\hline & centre & $26.16 \%$ \\
\hline & south (except Ho Chi Minh City) & $2.14 \%$ \\
\hline & Ho Chi Minh City & $0.20 \%$ \\
\hline time at present address & $(0-2)$ & $0.71 \%$ \\
\hline \multirow[t]{5}{*}{ (in years) } & $(2-5)$ & $0.68 \%$ \\
\hline & $(5-10)$ & $1.35 \%$ \\
\hline & $(10-20)$ & $2.95 \%$ \\
\hline & $(20-60)$ & $4.86 \%$ \\
\hline & other & $34.89 \%$ \\
\hline \multirow[t]{5}{*}{ residential status } & home owner (home not used as collateral) & $3.36 \%$ \\
\hline & home owner (home used as collateral) & $0.64 \%$ \\
\hline & living with parents & $2.94 \%$ \\
\hline & rental & $2.36 \%$ \\
\hline & other & $0.71 \%$ \\
\hline \multirow[t]{4}{*}{ marital status } & married & $3.40 \%$ \\
\hline & single & $2.19 \%$ \\
\hline & widowed, divorced & $2.27 \%$ \\
\hline & other & $5.75 \%$ \\
\hline \multirow[t]{5}{*}{ number of dependants } & 0 & $1.06 \%$ \\
\hline & 1 & $3.06 \%$ \\
\hline & 2 & $2.46 \%$ \\
\hline & 3 & $4.33 \%$ \\
\hline & $>3$ & $6.69 \%$ \\
\hline
\end{tabular}


Table 4 (cont.)

Variables included in the Vietnamese retail credit scoring model

\begin{tabular}{|c|c|c|}
\hline variables & categories & default \\
\hline \multirow[t]{2}{*}{ home phone } & yes & $0.92 \%$ \\
\hline & no & $8.53 \%$ \\
\hline \multirow[t]{2}{*}{ mobile phone } & yes & $0.40 \%$ \\
\hline & no & $4.41 \%$ \\
\hline \multirow[t]{5}{*}{ loan purpose } & business & $5.05 \%$ \\
\hline & house & $0.95 \%$ \\
\hline & collateralized & $11.96 \%$ \\
\hline & general credit & $1.29 \%$ \\
\hline & credit card & $0.10 \%$ \\
\hline \multirow[t]{4}{*}{ collateral type } & real estate & $0.41 \%$ \\
\hline & mobile asset & $7.13 \%$ \\
\hline & fixed asset (machine) & $2.86 \%$ \\
\hline & no collateral & $7.30 \%$ \\
\hline collateral value & $(0-50)$ & $5.57 \%$ \\
\hline \multirow[t]{4}{*}{ (in million VND) } & $(51-100)$ & $4.62 \%$ \\
\hline & $(101-500)$ & $0.68 \%$ \\
\hline & $(501-1000)$ & $0.24 \%$ \\
\hline & $(>1000)$ & $0.20 \%$ \\
\hline loan duration & $(<13)$ & $2.37 \%$ \\
\hline \multirow[t]{4}{*}{ (in years) } & $(13-24)$ & $1.59 \%$ \\
\hline & $(25-36)$ & $3.12 \%$ \\
\hline & $(37-48)$ & $7.35 \%$ \\
\hline & $(>48)$ & $2.16 \%$ \\
\hline time with bank & $(<13)$ & $2.38 \%$ \\
\hline \multirow[t]{3}{*}{ (in years) } & $(13-24)$ & $5.62 \%$ \\
\hline & $(25-36)$ & $4.30 \%$ \\
\hline & $(>36)$ & $0.95 \%$ \\
\hline \multirow[t]{4}{*}{ number of loans } & 1 & $7.94 \%$ \\
\hline & 2 & $1.49 \%$ \\
\hline & 3 & $0.74 \%$ \\
\hline & $>3$ & $0.15 \%$ \\
\hline \multirow[t]{2}{*}{ current account } & yes & $1.34 \%$ \\
\hline & no & $4.22 \%$ \\
\hline \multirow[t]{2}{*}{ savings account } & yes & $0.11 \%$ \\
\hline & no & $3.54 \%$ \\
\hline
\end{tabular}


Table 5

The credit scoring model's variables and estimated coefficients

Note that the variables are selected based on the stepwise method. In this table the included variables are ranked by absolute value of the coefficients.

\begin{tabular}{lrrr}
\hline included variables & $\begin{array}{r}\text { estimated } \\
\text { coefficient }\end{array}$ & $\begin{array}{r}\text { standard } \\
\text { error }\end{array}$ & $\begin{array}{r}\text { significance } \\
\text { level }\end{array}$ \\
\hline time with bank & -1.774 & 0.121 & $0.0 \%$ \\
gender & -1.557 & 0.222 & $1.0 \%$ \\
number of loans & -0.938 & 0.051 & $1.4 \%$ \\
loan duration & -0.845 & 0.080 & $3.7 \%$ \\
deposit account & -0.750 & 0.104 & $3.1 \%$ \\
region & -0.652 & 0.030 & $13.6 \%$ \\
residential status & -0.551 & 0.278 & $44.6 \%$ \\
current account & -0.492 & 0.208 & $10.4 \%$ \\
collateral value & -0.402 & 0.096 & $9.8 \%$ \\
number of dependants & -0.356 & 0.096 & $9.9 \%$ \\
time at present address & -0.285 & 0.054 & $2.5 \%$ \\
marital status & -0.233 & 0.101 & $68.1 \%$ \\
collateral type & -0.190 & 0.057 & $53.0 \%$ \\
home phone & -0.181 & 0.047 & $3.4 \%$ \\
education & -0.156 & 0.067 & $60.3 \%$ \\
loan purpose & -0.125 & 0.054 & $3.3 \%$ \\
constant & -3.176 & 0.058 & $4.6 \%$ \\
\hline
\end{tabular}


Table 6

Predicted versus observed probabilities of default in the hold-out sample

Panel A: Default probabilities by loan group

probability of default (in \%)

\begin{tabular}{crrrrr} 
& number of & & \multicolumn{3}{c}{ predicted } \\
\cline { 3 - 6 } group & loans & observed & minimum & average & maximum \\
\hline 1 & 5,091 & 0.01 & 0.00 & 0.01 & 0.02 \\
2 & 4,956 & 0.08 & 0.03 & 0.06 & 0.12 \\
3 & 5,007 & 0.27 & 0.13 & 0.24 & 0.41 \\
4 & 4,929 & 1.11 & 0.42 & 0.77 & 1.79 \\
5 & 5,060 & 49.31 & 1.80 & 15.41 & 96.81 \\
total & 25,043 & 3.19 & 0.00 & 3.33 & 96.81 \\
& & & & & \\
\hline
\end{tabular}

\begin{tabular}{lccc} 
& \multicolumn{2}{c}{ prediction } & \\
\cline { 2 - 3 } observation & non-default & default & PCC \\
\hline non-default & 24,136 & 109 & $99.55 \%=$ PCC $_{\text {good }}$ \\
default & 397 & 401 & $50.25 \%=$ PCC $_{\text {bad }}$ \\
& & & $97.98 \%=$ PCC $_{\text {total }}$ \\
SENS & $98.38 \%$ & & \\
SPEC & & $78.63 \%$ & \\
& & \\
\hline Panel C: Predictive accuracy with an optimal cut-off of 0.1995
\end{tabular}

\begin{tabular}{lccc} 
& \multicolumn{2}{c}{ prediction } & \\
\cline { 2 - 3 } observation & non-default & default & PCC \\
\hline non-default & 199698 & 547 & $97.74 \%=$ PCC $_{\text {good }}$ \\
default & 599 & $75.06 \%=$ PCC $_{\text {bad }}$ \\
& $99.17 \%$ & $97.02 \%=$ PCC $_{\text {total }}$ \\
SENS & & $52.27 \%$ \\
SPEC & & \\
Panel D: A credit scoring model with two cut-offs of 0.01 and 0.21 \\
\hline
\end{tabular}

\begin{tabular}{lrrr} 
& \multicolumn{3}{c}{ prediction } \\
\cline { 2 - 4 } observation & non-default & marginal & default \\
\hline non-default & 19,023 & 4,681 & 541 \\
default & 40 & 155 & 603 \\
& & & \\
$\mathrm{~B}_{\mathrm{g}} / \mathrm{B}$ & $5.01 \%$ & & \\
$\mathrm{~B}_{\mathrm{b}} / \mathrm{B}$ & & & $75.56 \%$
\end{tabular}


Table 7

Risk-based loan pricing

\begin{tabular}{lrrrr} 
& \multicolumn{3}{c}{ borrower class } & \\
\cline { 2 - 4 } & low risk & moderate risk & high risk & all borrowers \\
\cline { 2 - 5 } range of predicted PD & $0.00 \%-0.04 \%$ & $0.05 \%-0.30 \%$ & $0.31 \%-19.95 \%$ & $0.00 \%-19.95 \%$ \\
number of loans & 7,424 & 7,557 & 7,842 & 22,823 \\
overhead cost & $1.00 \%$ & $1.50 \%$ & $2.00 \%$ & $1.50 \%$ \\
cost of funds & $9.00 \%$ & $9.00 \%$ & $9.00 \%$ & $9.00 \%$ \\
profit margin & $2.00 \%$ & $2.00 \%$ & $2.00 \%$ & $2.00 \%$ \\
& & & & \\
cost of default & $0.10 \%$ & $0.20 \%$ & $2.00 \%$ & \\
loan interest rate & $12.10 \%$ & $12.70 \%$ & $15.00 \%$ & $13.30 \%$ \\
& & & & \\
LD = average observed PD & $0.13 \%$ & $0.33 \%$ & $1.98 \%$ & $0.83 \%$ \\
LGD & $100.00 \%$ & $100.00 \%$ & $100.00 \%$ & $100.00 \%$ \\
cost of default = LD * LGD & $0.13 \%$ & $0.33 \%$ & $1.98 \%$ & $0.83 \%$ \\
loan interest rate & $12.13 \%$ & $12.83 \%$ & $14.98 \%$ & $13.33 \%$ \\
& & & & \\
\hline
\end{tabular}

